\title{
INFLUENCE OF DISCOUNT PRICE ANNOUNCEMENTS ON CONSUMER'S BEHAVIOR
}

\author{
INFLUÊNCIA DOS ANÚNCIOS DE DESCONTO SOBRE O COMPORTAMENTO DOS \\ CONSUMIDORES
}

INFLUENCIA DE LOS AVISOS DE DESCUENTO SOBRE EL COMPORTAMIENTO DE LOS CONSUMIDORES

\section{ABSTRACT}

The theoretical framework that underpins this research study is based on the Prospect Theory formulated by Kahneman and Tversky, and Thaler's Mental Accounting Theory. The research aims to evaluate the consumers' behavior when different patterns of discount are offered (in percentage and absolute value and for larger and smaller discounts). Two experiments were conducted to explore these patterns of behavior and the results that were obtained supported the view that the framing effect was a common occurrence. The patterns of choice of individuals in a sample were found to be different due to changes in the ways discounts were offered. This can be explained by the various ways of presenting discount rates that had an impact on the influence of purchase intentions, recommendations and quality perception.

KEYwORDS Purchase intent, consumer behavior, framing effect, discount, group purchasing website

Giuliana Isabella giuliana.isabella@gmail.com

Ph.D Student at Business Administration at Faculdade de Economia, Administração e Contabilidade, Universidade de São Paulo - São Paulo - SP, Brazil

Alexandre Ierulo Pozzani alexandre.pozzani@gmail.com

Graduate at Business Administration at Escola Superior de Administração e Gestão - Santo André - SP, Brazil

Vinicios Anlee Chen vinicioschen@hotmail.com

Graduate at Business Administration at Escola Superior de Administração e Gestão - Santo André - SP, Brazil

Murillo Buissa Perfi Gomes murillobuissa@hotmail.com

Graduate at Business Administration at Escola Superior de Administração e Gestão - Santo André - SP, Brazil

Resumo A Teoria de Perspectiva desenvolvida por Kahneman e Tversky e a teoria de contabilidade mental de Thaler foram utilizadas como base e estrutura teórica para elaborar este trabalho. Esta pesquisa busca avaliar o comportamento dos consumidores quando se oferecem diferentes modelos de desconto (no valor absoluto ou percentagem; descontos maiores e menores). Os modelos de comportamento foram explorados em dois experimentos. Os resultados desses experimentos demonstraram a presença de um efeito de enquadramento em termos gerais. Segundo essa premissa, os tipos de escolhas dos indivíduos em uma amostra são diferentes. Devido às mudanças da estrutura da oferta, as taxas de desconto variável tiveram um impacto na influência da intenção de compra, nas recomendações e na percepção da qualidade. Palavras-chave Intenção de compra, comportamento do consumidor, efeito de enquadramento, desconto, rede de compra coletiva.

Resumen La Teoría de Perspectiva desarrollada por Kahneman y Tversky y la teoría de contabilidad mental de Thaler fueron utilizadas como base y estructura teórica para elaborar este trabajo. Este estudio se propone evaluar el comportamiento de los consumidores cuando se ofrecen diferentes modelos de descuento (en el valor absoluto o porcentaje; descuentos mayores y menores). Los modelos de comportamiento fueron explorados en dos experimentos. Los resultados de dichos experimentos demostraron la presencia de un efecto de encuadramiento en términos generales. Según esa premisa, los tipos de opciones de los individuos en una muestra son diferentes. Debido a los cambios de estructura de la oferta, las tasas de descuento variable tuvieron un impacto en la influencia sobre la intención de compra, las recomendaciones y la percepción de la calidad.

Palabras clave Intención de compra, comportamiento del consumidor, efecto de encuadramiento, descuento, red de compra colectiva. 


\section{INTRODUCTION}

Understanding the variables that affect consumer behavior and the decision-making process is not just the work of big corporations (AILAWADI, BEAUCHAMP, DONTHU, GAURI, and SHANKAR, 2009), but also of professionals seeking to find the key areas of marketing studies. Among the variables that affect the consumer's purchase decision is the price, which has a significant influence on communication factors concerning the advantages of purchasing a product or hiring a service. Price can be accompanied by a "discount," which increases the perceived value of the product for the purchaser. The value is based on the consumer's perception of the benefits of the product vis-à-vis the price. Many factors influence the consumer's perception of value, such as the following: the initial price, the consumer's attitude to the product, the expertise of the consumer, and previous experience of the product.

Many studies of consumer perception use the Prospect Theory of Kahnemann and Tversky (1979) as a theoretical basis for their research. These authors suggest that consumers may have different perceptions of the same information depending on how it is presented. This change in the consumer's perception is called the Framing Effect, a concept that emphasizes that even if the key features of the decision-making situation are maintained without any alteration, such as alternatives, probabilities and results, consumers will have different perceptions of the same purchasing situation, a fact that should not occur in rational decision-making (TVERSKY and KAHNEMAN, 1981).

Serpa and Avila (2004) explain that the way price is presented (the Framing Effect) can have a strong impact on personal purchase decision-making. They conducted an experiment in which the only differences in the descriptions were in the discounted price. According to their study, the Framing Effect results from a subconscious decision-making process. They found that the marketers did not have more resistance to the Framing Effect than people in other professions; they did not make more rational decisions despite their knowledge of the pricing strategy. This confirmed that the framing effect also affected professional marketers, and showed that even when people had managerial experience in marketing, they were only partially aware of the Framing effect on price perception.

There has been a good deal of research on the different reactions consumers have when identifying prices in sales promotions, and how they affect their purchase decisions (AILAWADI, and others, 2009; PALAZÓN and DELGADO, 2009; SERPA and AVILA, 2004). For instance, Lichtenstein, Ridgway and Netemeyer (1993) analyzed price presentation formats (in the case of two negative perceptions and five positive perceptions) and determined their influence on the consumer's perceptions of price research, purchases of generic products, ability to memorize prices and response to price and promotion coupons. People react in different ways depending on their price perception.

DelVecchio, Krishanan and Smith (2007) described the Framing Effect on consumer's perceptions, and observed when customers paid more attention to promotional pricing. In particular, they compared cents-off promotions with percentage-off promotions. Palazón and Delgado-Ballester (2009) investigated the interaction effect between the promotional benefit level and the type of promotion at three levels of benefit (low, moderate and high) by conducting an experiment. On the basis of the results, they concluded that high benefit level price discounts are more effective than premiums, while low benefit level price discounts are a less effective way to increase purchase intention.

Ailawadi and others (2009) reviewed the marketing elements, especially promotion, advertising and other forms of communication that have been developed by researchers in recent decades. Their goal was to find out what the major issues will be in future research in these areas. One of their suggestions was to investigate new forms of media, in particular the online market. In the same line of inquiry, the study of Degeratu, Rangaswamy and Wu (2000) found that online consumers are more price-sensitive than offline consumers. Kannan and Kopalle (2011) added that it is easier to offer customized promotions that are targeted at individual consumers online. This distinction between different kinds of consumers suggests that "retailers should use different types of price promotion online" (AILAWADI, and others 2009, p. 51).

By examining the impact of price on purchasing decisions and taking the Internet environment into account, this paper explores the consumer reaction to an ad discount, and the extent to which it depends on the structure of the price presented (after cash or percentage deductions).

A group purchasing website, also known as cobuying, a group buying site, an aggregate buying and collective buying site (RHA and WIDDOWS, 2005), 
is a form of e-commerce, in which the goal is to sell products and services with a high discount to a predetermined minimum number of consumers. This website was used in this research, and addressed the discount issue that is growing in Brazil and already common in many countries in the world (RHA and WIDDOWS, 2005). This paper chose the Peixe Urbano (www.peixeurbano.com.br), one of the biggest groups purchasing websites in Brazil, as the base for discounts, products, and advertising. According to Peixe Urbano (2011), the collective buying market in Brazil is the third largest in the world in terms of unique visitors, and only exceeded by the U.S. and France.

Vieira (2008) states that one of the most important priorities in online retailing should be to provide a good quality service. Hence, this paper differs from others in so far as it concentrates on analyzing how consumers perceive the quality of a given product, and how they purchase it and recommend it to others.

Our paper is also distinct in offering alternative structures for discount and keeping the reference price of the same product when the final amount is paid through a bidding process. The cent-off discount scheme is commonly employed in the United States, and thus there has already been some research in this area (DELVECCHIO, and others, 2007). However, the double-digit discount that is commonly found in the group purchasing website has not been explored yet. Our research also sought to carry out an in-depth analysis of the sale discount services, which is an area that has been little explored compared to other product discounts. In addition, it compares the discount pattern in social networks, - markets that are increasingly gaining momentum. With regard to the theoretical dimension of research, our study outlines the theories of mental accounting and explores the concepts of purchase intention and quality perception.

\section{THE THEORETICAL FRAMEWORK}

\section{The prospect theory}

In their Prospect Theory, Kahneman and Tversky (1979) recognize that decision behavior is greatly influenced by cognitive difficulties. The term Framing Effect was employed to describe the phenomenon that occurs when there is a change in an individual's preference between two or more alternatives caused by the way the problem is presented (TVERSKY and KAHNEMAN, 1981).

In explaining the Framing Effect, the Prospect Theory interprets the individual's decision-making process in the context of uncertainty in two stages: the first stage involves an analysis of the problem, and results in the perception that influences the final decision and the second stage is an evaluation of the problem (FIGUEIREDO and ÁVILA, 2004).

The aim of the first stage of the decision-making process is to simplify the problem. The perceptions of the individual that result from the decision-making can be classified as gains and losses with regard to a reference point. If the results are perceived as gains, there will be greater emphasis on risk-taking but if when viewed from the reference point, the results are perceived as losses, there will be risk aversion. With regard to the reference point, the gains and losses are evaluated in terms of their subjective and personal value, which is called "utility," and measured by the degree of satisfaction associated with the decision's objectives (KAHNEMAN and TVERSKY, 1984).

The gain or loss is perceived as having greater or less intensity depending on its proximity to the reference point: for example, the subjective difference between a gain of $\$ 10$ and one of $\$ 20$ is more significant than the difference between $\$ 110$ and $\$ 120$. This cognitive operation is called Diminishing Marginal Sensitivity (THALER, 1985). It should be noted that the reference point basically consists of a value that an individual hopes to achieve; in practice, it can be defined as the value that an individual hopes to pay for a certain product (KAHNEMAN and TVERSKY, 1979).

According to Tversky e Kahneman (1984), a loss is felt much more than a gain, even if the loss or gain has the same value. The Loss Aversion Coefficient was calculated as 2.5 , so the sensation of loss is 2, 5 times greater than the sensation of gain for the same value. This means that a loss of $\$ 10$ is felt more than a gain of the same value, even if rationally the feeling of gain or loss should be the same. For instance, to obtain the same feeling of loss of $\$ 10$, a gain of $\$ 25$ would be necessary.

Figure 1 summarizes the conclusions of the Prospect Theory with regard to the reference point. In this chart, the horizontal axis represents the outcome of a certain decision; the vertical axis represents the subjective value of the results. "This function is defined in terms of gains and losses, not wealth. It is concave on the gains area and convex on the losses area; it is also steeper in the losses area" (SERPA and AVILA, 2000, p. 3). 
In an experiment, Tversky and Kahneman (1981) presented a situation and asked the participants, (students of Stanford and the British Columbia Universities), to choose one of two programs to solve a problem. The only difference between them was the presentation of the data: in Program A, the data were displayed in numerical form while in Program B; they were shown in percentage values. The problem was the following: "The USA is preparing to protect itself from a hypothetical outbreak of an Asian disease that can cause the death of 600 people." The two programs were: (A) "If you adopt Program A, probably 200 people will be saved," and (B) "If you adopt Program $\mathrm{B}$, there is a one-third probability that the total number of 600 people will be saved and a two-thirds chance that nobody will be saved." As a result, 72\% of the 152 participating students chose Program A, thus adopting a risk aversion stance. The two programs would save the same number of people: $1 / 3 * 600=200$. The purpose of this experiment was to explore the Framing Effect of the Prospect Theory, viewed from a perspective of gain.

The authors also carried out an experiment to explore the prospect of loss, using the same situation as that in the previous experiment but with statements emphasizing loss: (C) "If Program $\mathrm{C}$ is adopted, 400 people will probably die", and (D) "If Program D is adopted, there is a one-third probability that 600 people will die and a two-third probability that no one will die". In this second scenario, 78\% of the 155 participants chose Program D, which showed that in a loss perspective, there is a higher tendency to take risks.

Kahneman and Tversky (1984) explored the question of price promotion with the objective of validating how Framing Effects apply to other contexts. As in the previous example, the participants were presented with a situation that required conveying a purchase intention. The first situation was a sales promotion of jackets in a store near the consumer's

\section{Figure 1 - Value function}

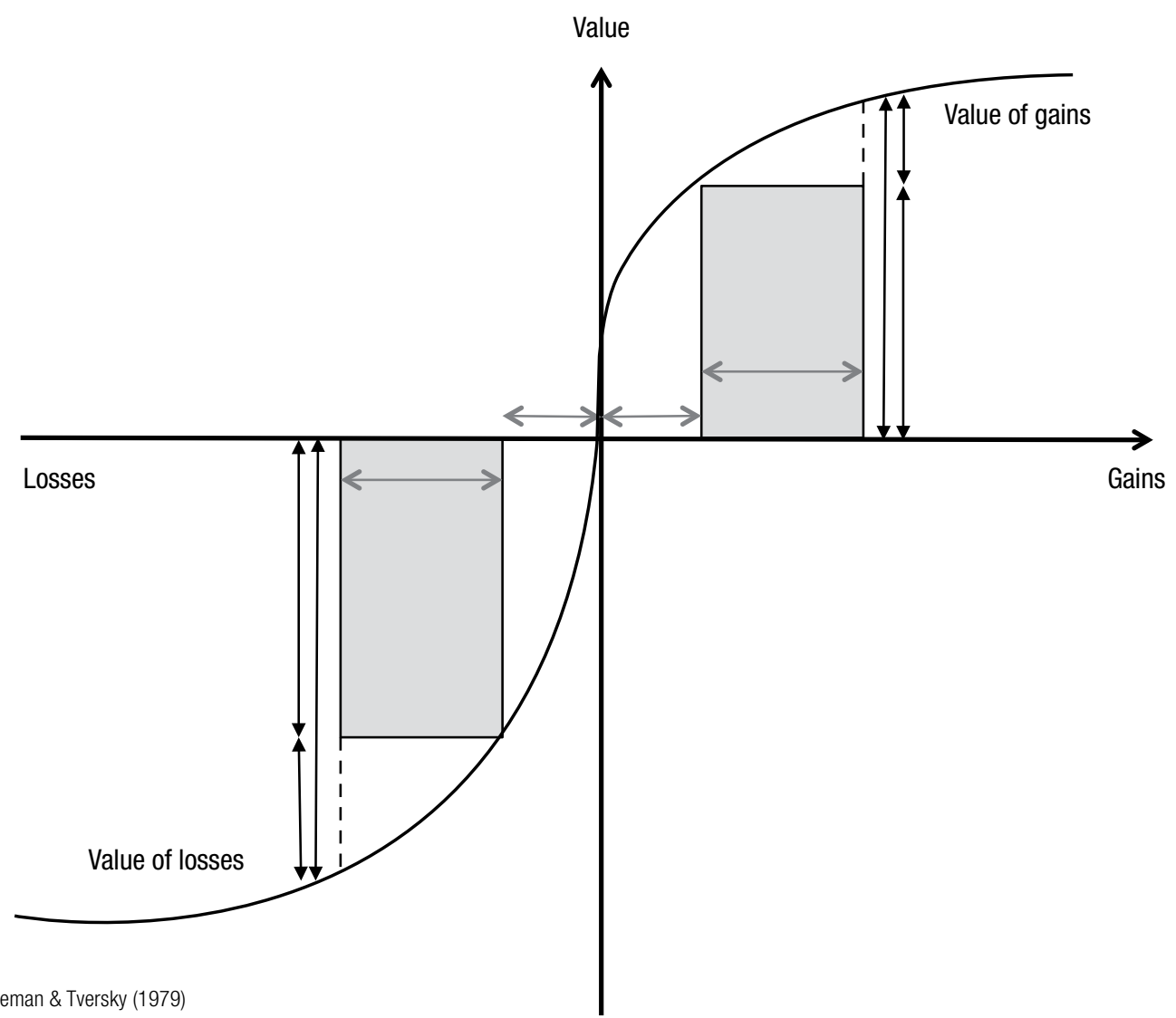


home; the regular price was $\$ 125$ and the promotion price was $\$ 120$ (or refusal to buy). The second situation was a sales promotion of calculators in a store at a comparable distance from the consumer's home; the regular price was $\$ 15$ and the promotion price was $\$ 10$ (or refusal to buy). The discount of both products was exactly the same $(\$ 5.00)$ and in a rational decision, there would be no preference. However, the outcome of the experiment was that $68 \%$ of the participants preferred to buy the calculator compared with $29 \%$ that preferred to buy the jacket with the same $\$ 5$ discount.

According to Liechestein, Ridgeway and Netemeyer (1993), an increase in price sensitivity is directly related to the price presentation format; for instance, a discount on the regular selling price (i.e. a regular price of $\$ 1.99$ vis-à-vis a discounted price of \$1.29) increases price sensitivity. Advertising a product with a reference price and discount increases its value perception and, consequently, the value of the offered discount.

As the study of Russo and Schoemaker (1989) makes clear, people tend to think in percentage terms, not in absolute values, whereas the processing of gains and losses is carried out in relative terms. Some studies agree that consumers may prefer a sales promotion that is framed in a pattern that involves percentages (e.g. MORWITZ and others 1998). On the other hand DelVecchio, Krishanan and Smith (2007) did not find a significant difference in the experiment that involved comparing a percentage discount and cents-off scheme. They expected that the consumer would be encouraged to prefer the discount offered in the percentage-off scheme, but this did not occur. On the basis of these studies, we believe that consumers may prefer a sales promotion that is framed in percentage-off terms when the discount is found to be a high discount rate. However, when the discount is small, and shown in the form of cents, the consumers tend to prefer it stated as an absolute value.

H1A: In high discounts, there will be a higher purchasing intention in the offer with a percentage discount.

H1B: In low discounts, there will be a higher purchasing intention in the offer with an absolute discount.

One of the principles studied by Thaler (1985), and based on the Prospect Theory, shows that combining lower losses and higher gains in accounting is preferable to keeping losses and gains apart. In other words, showing a final value with gains, even if it is lower, is preferable to showing a lower loss in front of a higher gain.

The inclusion of a reference price, according to Heath, Chatterjee, and France (1995), can make a difference since the principles of mental accounting for maximum satisfaction were derived and tested without taking the reference price into consideration. A discount of $\$ 5.00$ with a reference value of $\$ 10.00$ is more attractive than the same $\$ 5.00$ with a reference value of $\$ 100.00$, as shown in the sales promotion of jackets in the experiment by Kahneman and Tversky (1984) discussed earlier.

Lower reference prices cause a perception of higher gain when compared to higher reference prices, resulting in a higher purchase intention (NIEDRICH and others 2001). However, our hypothesis is that the biggest discount rate is the most appealing. If the final price was the same, but the reference price was different, the participants preferred the items that had the biggest discount rate.

In the case of this research, the final rate of the service price will be the same for all the participants (\$19.00), and the reference prices shown in the offer are $R \$ 30.00$ and $R \$ 50.00$. In this instance, the purchase intention will be higher for the offer presented with a discount of $62 \%$, compared with the offers presented with discounts of $37 \%$. However, the findings in the literature show that sales promotion based on prices can lower consumer's perceptions of brand quality (DODSON, TYBOUT, and STERNTHAL, 1978). The relationship between price and quality has been studied by various authors (MCCONNELL, 1968; VERMA and GUPTA, 2004; ZEITHAML, 1988). The quality perception of a product or service is acquired through variables such as brand, packaging, purchasing channels, advertising and others (VERMA and GUPTA, 2004).

Verma and Gupta (2004) analyzed quality perception with regard to price by using a television set as the sample product. As a result, the higher prices revealed a higher perception of quality by the consumer. In the case of durable products (such as televisions), the study showed that people view brand name products or higher prices as signs of higher quality. According to the authors, "for a durable product, a lower price fixation can negatively affect the quality image of the product and the consumer is not willing to buy a lower price brand" (VERMA and GUPTA, 2004, p. 67). In the case of low-involvement products, they chose toothpaste as the 
product for their study. The 171 participants judged the quality of a toothpaste tube in six different price classes with the aim of showing how the quality perception of an object varies according to the price. The participants judged the value of the product according to the price: higher prices lead to higher quality and vice versa.

Price is a factor that influences the product evaluation process, as it is present in every purchasing situation, and represents the amount of economic effort that has to be made to ensure a satisfactory purchase (LICHTENSTEIN; RIDGWAY; NETEMEYER, 1993). The use of price as a quality indicator depends on the availability of other variables that can interfere with the quality such as brand, price variation in a product category or the consumer's awareness of the price, and his/her capacity to distinguish between the variations of the quality in a product group (ZEITHAML, 1988).

With regard to services, there are a few tangible characteristics; in this case, these features were often limited to the structure of the service provider, equipment and people involved in its provision. In the absence of these tangible features, price becomes the main indicator of quality (PARASURAMAN, ZEITHAML, and BERRY, 1988).

This information provides evidence that the online discount service is in a collective purchase website, although the biggest discount rate could not attract the consumer because the quality perception was low. Consumers need to be anchored to some information and this includes the price, as usually occurs in this kind of online market where the participants have no previous knowledge of the brand. On the basis of this, the following two hypotheses are put forward:

H2: In a "same price" situation, the biggest discount rate will not attract the consumer.

$\mathrm{H} 3$ : In a situation where a higher discount rate is perceived, there is a decline in quality perception.

The objective of this article is to determine the presence of the Framing Effect and its applications to offers in a group purchasing website, by attempting to validate the quality perception of discounts in service situations.

\section{METHODOLOGY}

Two laboratory experiments were carried out to test the hypotheses. Figure 2 shows the objective of the studies.

\section{Figure 2 - Graphical presentation of the conceptual model}

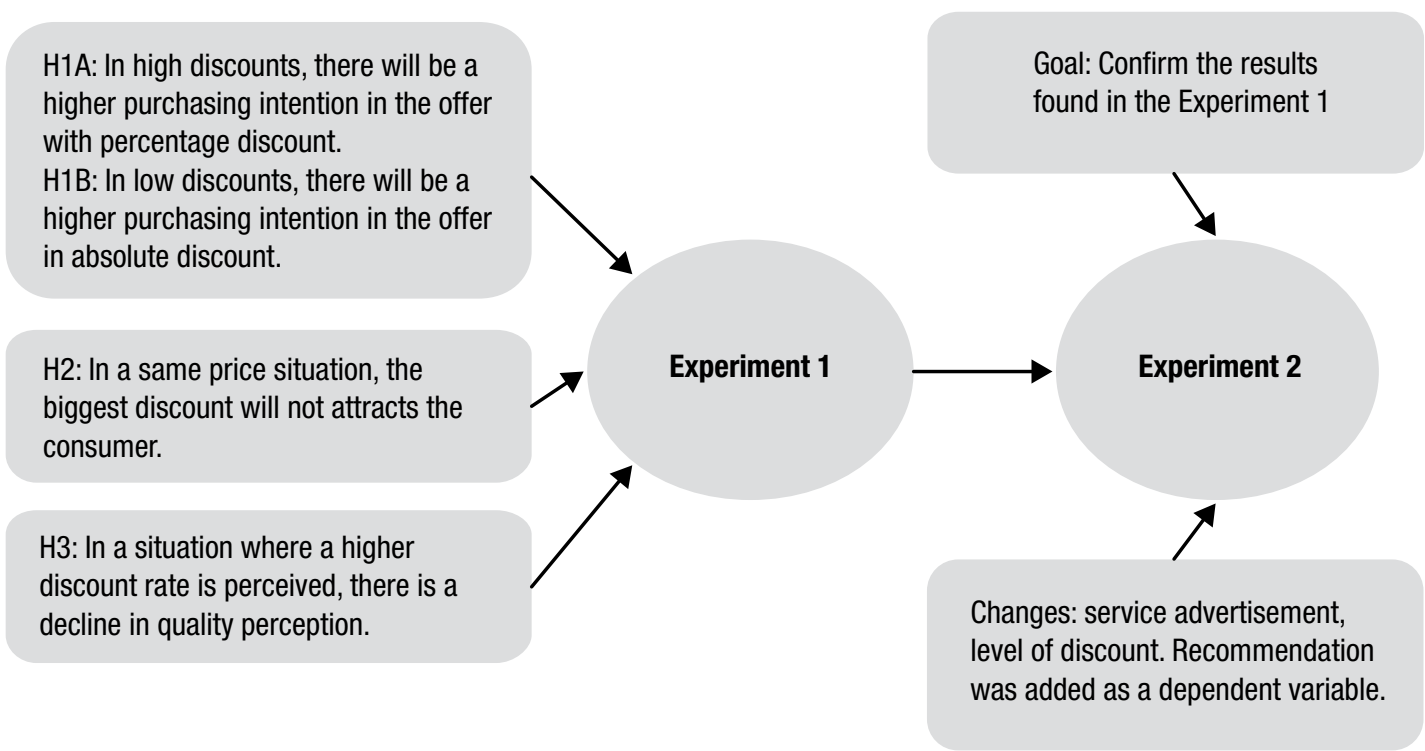




\section{Experiment 1}

Students from a school of Business Administration and Management in Santo André participated in an experiment to evaluate the presence of the Framing Effect, which was prepared as factorial $2 \times 2$. The first deciding factor referred to the way the discount is advertised (in percentage terms and in Reals, the Brazilian currency), and the second referred to the amount of the discount (from a low discount - R $\$ 11.00$ to a large discount - R\$31.00). By means of these factors, four distinct ads were created, all of which were very similar to those in the Peixe Urbano website. The stimulus/ad was composed of a header, which described the offer, along with the discounted model, followed by a photo of the product and ending with a list of general conditions. The name of the pizzeria pizza restaurant was fictitious, to avoid the risk of biased results. The product used was a pizza, which was meant to be consumed in the restaurant.

The same final price of the offered product (the pizza) was used in the four ads. The price of the final pizza was $\$ 19.00$ and based on the average price of Marguerita toppings found in three pizzerias in the region where the experiment was conducted. When determining the value of the discount rate, the same decimal number was selected as that of the last digit in the decimal. The choice of the pizzas from the pizzerias was made in the light of the following factors: first, most group purchasing websites operate through a coupons scheme for services, not products. Second, exploring the sale of services rather than products, (which have already been explored on other occasions), could be of greater value. Moreover, according to research conducted in 2011 by ABMN (Brazilian Association of Marketing \& Business), food is the main expense of young people in São Paulo, and on average, costs 95\% of them R\$229,10 per month (MAGALHÃES, 2010). There were no specific pizza toppings defined in the ad, which meant the consumer was given the choice of how to spend the value of the coupon in the pizza restaurant.

Two questions were adapted for this study from Lichtenstein, Ridgway and Netemeyer (1993) (one regarding purchase intention and the other regarding quality perception). The item was scored on a scale of 1-7 ranging from "definitely no" to "surely yes" (Example: "Would you buy this offer?"). A question about how much the participant usually pays for a pizza was also asked so that it could be used as a covariate.
The data collection occurred in May 2011 during night classes, after prior authorization had been granted by the teachers. One of four ads was distributed randomly to the participants in each classroom. This experiment involved a sample of 158 participants (students in higher education, and residents in the metropolitan region of São Paulo). Of this total, the average age of the participants was $21 ; 50 \%$ were male/female and $76 \%$ had a job. Table 1 shows the cells of the experiment with the number of people participating and also the number of models that were used in the analyses.

\section{Analyses}

As a manipulation check two questions were asked: "what is the final price of the offer?" and "what is the value of the discount?" Of the 158 participants, 17 participants $(10.75 \%$ of the sample) responded in a different way from what was expected. However, these were kept in the sample, since, in real life, many consumers, have difficulty in understanding percentage calculations.

Pearson Chi Square was performed to determine possible differences in the sample. As a result no gap was found. When the four condition were analyzed, it was found that the male and females in percentage terms and in the real sample did not influence $\mathrm{F}_{\text {Sex }}(1$, $\mathrm{N}=158)=2,532 ; \mathrm{p}=, 112$; the same results were found in Low and High Values $\mathrm{F}_{\text {Sex }}(1, \mathrm{~N}=158)=1,621 ; \mathrm{p}=, 203$. Whether the students worked or not did not influence in Percentage and Real sample $\mathrm{F}_{\text {work }}(1, \mathrm{~N}=158)=1,456$; $\mathrm{p}=0,228$; in Low and High Values $\mathrm{F}_{\text {Sex }}(1, \mathrm{~N}=158)=0,080$; $\mathrm{p}=, 777$.

\begin{tabular}{|c|c|c|}
\hline & \multicolumn{2}{|c|}{ Discount } \\
\hline & Low & High \\
\hline In percentage & $\begin{array}{c}37 \% \\
\mathrm{~N}=39 \\
\text { Model } 1\end{array}$ & $\begin{array}{c}62 \% \\
\mathrm{~N}=39 \\
\text { Model } 2\end{array}$ \\
\hline In real & $\begin{array}{c}\mathrm{R} \$ 11 \\
\mathrm{~N}=41 \\
\text { Model } 3\end{array}$ & $\begin{array}{c}\mathrm{R} \$ 31 \\
\mathrm{~N}=39 \\
\text { Model } 4\end{array}$ \\
\hline
\end{tabular}




\section{Analysis of the hypothesis}

The Generalized Linear Model (GLM) was used to validate the hypothesis. The GLM is a flexible model for generalized linear regression that includes the average and dispersion. Although, Levene's test was higher than 0.05 , confirming that the null hypothesis is correct and the ANOVA is appropriate (FIELD, 2009; PESTANA and GAGEIRO, 2008, the GLM was used because it is a "stronger" test (MYERS, MONTGOMERY and VINING, 2002) and allows the interaction between the independent variables to be shown. The analyses were conducted with the aid of the SPSS Statistics.

The first hypothesis states that there will be a higher purchase intention for the offer when the discount structure is perceived to be higher in relative terms. To assess the discount price advertisement, an ANOVA model was employed with intention purchase as the dependent variable and using the main effect of treatment and interaction as the dependent variables. Figure 3 is a graphical representation of the effect of discount format and level of discount on purchase intention. The means in the model are presented as follows: mean $_{\text {Model1 }}=3,821 ;$ mean $_{\text {Model2 }}=4,769 ;$ mean $_{\text {Model3 }}$ $=4,415 ; \operatorname{mean}_{\text {Model }}=3,923$. The data shows that when the discount price is low, the participants have a higher purchase intent score when the discount is shown in Real (Brazilian currency), but when the discount price is high the participant showed a greater preference for the percentage discount rate. The GLM confirms that there is a significant interaction in the model $\mathrm{F}(1,154)$
$=12,347 ; \mathrm{p} \leq 0,001)$. The complete model is displayed in Table 2 . The covariate proposed in the methodology was used in the regression.

The explanation for this result can be inferred from the analysis of the reference price. It is observed that the discount rate of $\mathrm{R} \$ 11.00$ is less than the final price of $\mathrm{R} \$ 19.00$. However, the amount seems to be similar, and conveys a feeling of a reduction that is almost $50 \%$, although this is not the case since the original value of the product offered was $\$ 30.00$. The result confirms to the theory that when the discount values are close to the reference values, it can increase the purchase intent in terms of absolute values (KAHNEMAN and TVERSKY, 1979; THALER, 1985).

A comparison of models 1 and 3 shows that there is a significant difference $\left(\right.$ mean $_{\text {Model } 1}=3,82$ versus mean $\left._{\text {Model3 }}=4,41\right)$. The result confirms that the participants offered low discounts have a high purchase intent score when the discount is presented in a currency like the Real $(F(1,79)=4,31 ; \mathrm{p}=0,041)$.

Since it was assumed that the discount of $62 \%$ (Model 2) would cause a higher impact on the consumer purchase intention with regard to discount, than the same discount structured in $\mathrm{R} \$ 31.00$ (Model 4), the outcome was as expected and the framing effect on the presentation of the discount structure is supported. When the averages in Models 2 and 4 (high discount) are compared by ANOVA, it can be seen that the discount rate presented in percentage terms (mean $=4,77)$ versus Real (means $=3,92)$, is statistically significant $F(1,78)=8.310, p=0,005$. This suggests that the best discount for the participants was when

\section{Table 2 - GLM - Purchase intention}

\begin{tabular}{|c|c|c|c|c|c|}
\hline \multicolumn{6}{|c|}{ Dependent variable: Would you buy this promotional product? } \\
\hline Source & $\begin{array}{l}\text { Type III Sum } \\
\text { of squares }\end{array}$ & df & Mean square & $\mathbf{F}$ & Sig. \\
\hline Corrected model & $37.581^{\mathrm{a}}$ & 4 & 9.395 & 5.971 & 0.000 \\
\hline Intercept & 344.986 & 1 & 344.986 & 219.240 & 0.000 \\
\hline Covariate: How much do you usually pay for a pizza & 14.633 & 1 & 14.633 & 9.299 & 0.003 \\
\hline Percentage versus $\mathrm{R} \$$ & 0.704 & 1 & 0.704 & 0.447 & 0.505 \\
\hline Level of discount & 2.425 & 1 & 2.425 & 1.541 & 0.216 \\
\hline Percentage versus $\mathrm{R} \$$ * level of discount & 22.157 & 1 & 22.157 & 14.081 & 0.000 \\
\hline Error & 240.754 & 153 & 1.574 & & \\
\hline Total & 3111.000 & 158 & & & \\
\hline
\end{tabular}

a. R Squared $=.082$ (Adjusted R Squared $=.065$ ) 
it was presented as a percentage rather than when it was presented as an absolute value.

Therefore, the data indicates that in the case of a low discount rate, there is a high purchase intent score for the Real; and with a high discount rate, there is high purchase intent when the discount is presented as a percentage. These results support hypotheses 1A and 1B.

Hypothesis 2 supposes that in a same price situation, the consumer will not prefer the biggest discount. This was compared with Models 1 and 2, and Models 3 and 4.
When the percentage (Models 1 and 2) was first analyzed, the data showed that Model 1 has mean $=3,82$ $(\mathrm{N}=39)$ and Model 2 has 4,77 ( $=39)$. Table 3 shows the main effect, and that there is a significant difference between the low discount and the high discount $F(1,78)=13,565, p<0,001$. The purchase intent had the biggest discount of $62 \%$, because the original price of the product discount structure was significantly higher than the original price of the offer of $37 \%$. This result contradicts the hypotheses proposed in the literature.

\section{Figure 3 - Comparison of the average purchase intent of the deal}

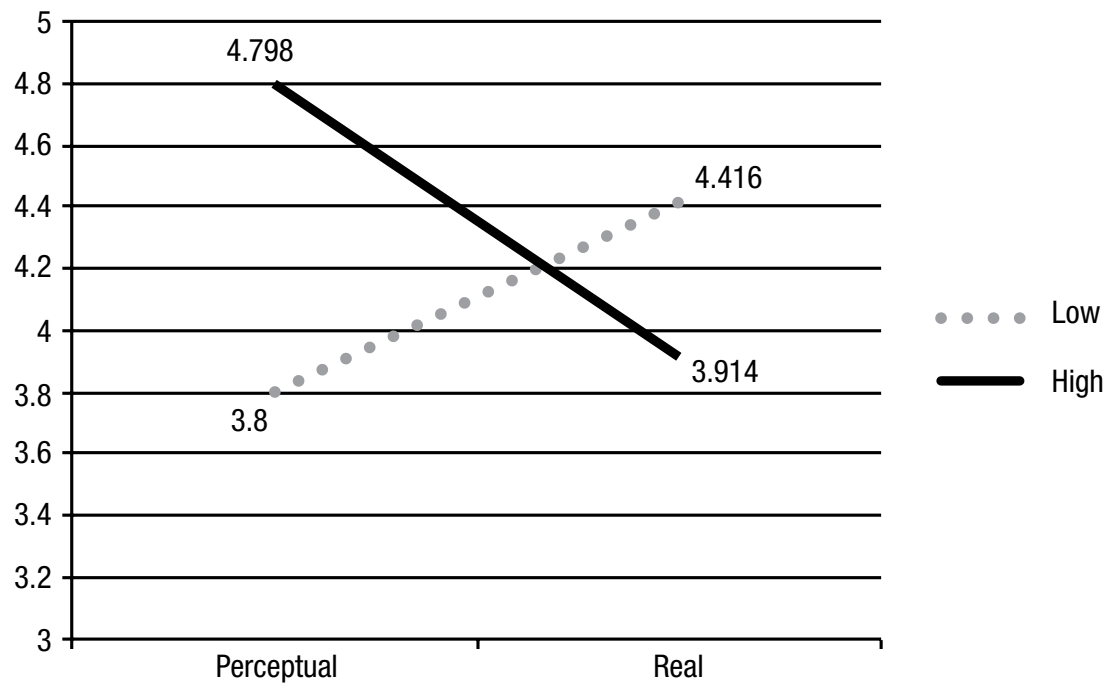

Table 3 - GLM - Purchase intention as a percentage

\begin{tabular}{|l|c|c|c|c|c|}
\hline \multicolumn{1}{|c|}{ Dependent variable: Would you buy this promotional product? } \\
\hline \multicolumn{1}{|c|}{ Source } & $\begin{array}{c}\text { Type III Sum of } \\
\text { squares }\end{array}$ & df & $\begin{array}{c}\text { Mean } \\
\text { square }\end{array}$ & F \\
\hline Corrected model & $43.478^{a}$ & 2 & 21.739 & 14.210 \\
\hline Intercept & 153.073 & 1 & 153.073 & 100.057 \\
\hline Covariate: How much do you usually pay for a pizza & 25.927 & 1 & 25.927 & 16.947 \\
\hline Level of discount & 20.752 & 1 & 20.752 & 13.565 \\
\hline Error & 114.740 & 75 & 1.530 & 0.000 \\
\hline Total & 1597.000 & 78 & & 0.000 \\
\hline Corrected total & 158.218 & 77 & & \\
\hline
\end{tabular}

a. $\mathrm{R}$ Squared $=.275$ (Adjusted R Squared $=.255)$ 
When Models 3 and 4 are analyzed, one can verify that for the low discount, the intention mean was 4,41 and for the large discount, the mean was 3,92. There was no significant difference between the low and the high discounts $\mathrm{F}(1,80)=3,235, \mathrm{p}=0,076$. The analysis shows that it is not possible to confirm that in terms of Real, a bigger discount will increase the purchase intention, assuming 95\% level of confidence. This suggests that hypothesis $\mathrm{H} 2$ can be supported. However, this is not entirely the case because there was an evident preference for the highest discount in the percentage discount rate.

To determine how the participants see the quality of the advertisement, the third hypothesis was analyzed by GLM. Again the covariate was used in the model. The means that were employed to calculate the covariate in the interaction model are: $\operatorname{mean}_{\text {Model1 }}=6,476 ;$ mean $n_{\text {Model2 }}=6,785$; $\operatorname{mean}_{\text {Model3 }}=6,781 ;$ mean $_{\text {Model4 }}=6,482$. The test shows an interaction between the discount level and discount structure that can be expressed as $F(1,158)=6,558 p=0,011$. The quality of the service/ product being advertised is higher in two situations: when the discount is low and presented in Reals and when the discount is high but presented as a percentage. When the discount is low and presented in percentage terms or the discount is high but appears as Reals, the quality perception is lower. Table 4 displays the complete model. This result is in accordance with $\mathrm{H} 1 \mathrm{~A}$ and $\mathrm{H} 1 \mathrm{~B}$, but cannot completely support $\mathrm{H} 3$.

\section{Experiment 2}

The second experiment was conducted to confirm the results obtained from the first experiment, which suggested that the differences between the structural presentations could change consumer behavior, and also aimed at analyzing if quality perception is one of the moderators of this behavior. Quality perception is one possible explanation why consumers do not see a high discount as being a very attractive choice. This experiment also seeks to analyze the results found in the first experiment where a different advertisement and different percentages were used.

An advertisement about a service, that also used the Peixe Urbano webpage design, was created to validate the results obtained from the first experiment. The service offered was a car inspection (wheel alignment and tire balancing). The factor design was: 2 (discount structure - Real versus Percentages) X (High and Low discount), between subjects. The discounted prices this time were the same as the prices in Real; the only difference was the percentage symbol. The total cost of the service was $\mathrm{R} \$ 100.00$, so the low discount was $25 \%$, or $\mathrm{R} \$ 25.00$, and the high discount was $75 \%$, or $R \$ 75.00$. This total price was intended to make it easier for the participants to calculate the discount. One example of the manipulation sentence is: "Deal of the Day: more security for you and your car! With $25 \%$ discount you pay only $\mathrm{R} \$ 75,00$ at Center Automotive Formula GP" After this sentence, in all the models, it was exposed a photo of a mechanic working, the logo of the Center Automotive and the rules of the advertising.

\section{Table 4 - GLM - Quality}

\begin{tabular}{|c|c|c|c|c|c|}
\hline \multicolumn{6}{|c|}{ Dependent variable: What do you think is the quality of this pizza? } \\
\hline Source & $\begin{array}{c}\text { Type Ill Sum of } \\
\text { squares }\end{array}$ & df & Mean square & $\mathbf{F}$ & Sig. \\
\hline Corrected model & $7.710^{\mathrm{a}}$ & 4 & 1.927 & 3.470 & 0.010 \\
\hline Intercept & 1065.471 & 1 & 1065.471 & 1917.872 & 0.000 \\
\hline Covariate: How much do you usually pay for a pizza & 4.436 & 1 & 4.436 & 7.984 & 0.005 \\
\hline Level of discount & 0.001 & 1 & 0.001 & 0.002 & 0.966 \\
\hline Percentage versus $\mathrm{R} \$$ & 0.8617 & 1 & 0.08617 & 0.000 & 0.990 \\
\hline Level of discount * percentage versus $\mathrm{R} \$$ & 3.643 & 1 & 3.643 & 6.558 & 0.011 \\
\hline Error & 84.999 & 153 & .556 & & \\
\hline Total & 7044.000 & 158 & & & \\
\hline Corrected total & 92.709 & 157 & & & \\
\hline
\end{tabular}

R Squared $=.083(\text { Adjusted R Squared }=.059)_{\text {a }}$ 
It was decided that a car service should be used to illustrate this manipulation, because many of the services offered for collective purchase in Brazil are related to cars. Using a manipulation with a common service offered online, is closer to the reality of collective purchases and conveys a sense of credibility.

The experiment was conducted by means of Qualtrics software, and the link created was suitably attached and disseminated to the authors' network. The software randomly assigned a condition for each participant.

Four selected questions were used as dependent variables: two about purchase intention, one about recommendation and one about quality perception (BERENS, VAN RIEL and VAN BRUGGEN, 2005). The questions were as follows: if you were planning to use this type of service, how likely would you be to choose this one? If a friend were looking for a service like this, how likely would you be to recommend this one? With the sales promotion can I get a better quality service elsewhere for the same total price? The three dependent variables were rated on the Likert scale with a score of $1-7$ points. The frequency of buying on a collective purchase website was used as a covariate.

The data collection took place in April/May of 2012 over the course of 20 days. The people who received the links were asked to send it to friends. This experiment involved a sample of 196 participants; however, only 131 answered more than $90 \%$ of the questions. From this sample, 85 had their own car, 11 used their family car but were responsible for it, and $35 \mathrm{did}$ not have a car. The people who did not have a car were excluded from the experiment because they could not state their purchase intentions or quality perception of a car service. Table 5 shows the number of participants in each condition.

Of these 96 participants, 53 were male, 86 said that they worked and 5 said that they were unemployed; 21 said that they had never bought any service online; 52 were single and 30 were married; 76 had graduated and the mean age was 32 years old.

\section{Analysis}

The analysis was conducted with the aid of SPSS Statistics. The same manipulation check employed for the first experiment was used for the second one. Of 96 participants, 3,125\% did not answer 1-2 questions correctly and 13,542\% left them blank. As decided in the first experiment, these participants were not excluded from the analysis.

\section{ANALYSIS OF THE HYPOTHESIS}

Levene's test was used to measure normality. In all the dependent variables, Levene's test was higher than 0,05, confirming that ANOVA is suitable (FIELD, 2009; PESTANA and GAGEIRO, 2008). However, it was again decided to use the General Linear Model, to check the interaction and also a covariate.

The first hypothesis, - whether there will be a higher purchase intention in the offer with the discount structure that is perceived to be higher, in relative terms, - was validated by using the purchase intention as a dependent variable in the GLM. The means in the model are as follows: mean $_{\text {Model } 1}=3,655$; $\operatorname{mean}_{\text {Model2 }}=4,210 ;$ mean $_{\text {Model3 }}=3,521 ;$ mean $_{\text {Model } 4}=$ 2,745 . The GLM verifies that there is not a significant interaction in the model $\mathrm{F}(1,90)=2,847 ; \mathrm{p}=$ 0,095). However, the main effect of discount rates is significant $F(1,90)=3,970 ; p=0,050$. The data indicates that in a high discount rate, there is a high intention purchase when the discount is presented as a percentage. In low discount rates, the scores between the discount and the Real currency is similar and do not corroborate the results obtained from Experiment 2. These results support H1A, but not H1B. The complete model is displayed in Table 6 . Figure 4 graphically presents the effects of the discount format and level of discount on purchase intention. It is probable that the participants did not regard $\mathrm{R} \$ 25,00$ as a low discount.

The same analysis was carried out for the dependent variable - recommendation. As a result, an interaction was found between the discount rates and the level of discount $(F(1,91)=5,852, p=0,018$. The means were: mean $_{\text {Model1 }}=3,897 ;$ mean $_{\text {Model } 2}=4,576 ;$ mean $_{\text {Model3 }}$ $=3,941 ;$ mean $_{\text {Model } 4}=2,637$. As in the first experiment, the participants preferred sales promotions with high discounts in percentage terms. In the case of low

\section{Table 5 - Summary of discount conditions shown for each cell of the experiment}

\begin{tabular}{|l|c|c|}
\hline \multirow{2}{*}{} & \multicolumn{2}{|c|}{ Discount } \\
& Low & High \\
\hline In percentage & $25 \%$ & $75 \%$ \\
& $\mathrm{~N}=24$ & $\mathrm{~N}=16$ \\
\hline In real & $\mathrm{R} \$ 25,00$ & $\mathrm{R} \$ 75,00$ \\
& $\mathrm{~N}=28$ & $\mathrm{~N}=28$ \\
\hline
\end{tabular}


discounts, no differences were found, perhaps because $\mathrm{R} \$ 25,00$ is not as low as $\mathrm{R} \$ 11,00$.

When the second hypothesis was tested, in the same price situation, the biggest discount perception has the consumer's strongest preference; it was found that the consumers preferred the largest discount as shown when Models 1 and 2, and then Models 3 and 4 are compared. When the percentage is first analyzed, the GLM shows $F(1,37)=1,026, p<0,318$ which means that there is no significant difference between the intention scores. When Models 3 and 4 were analyzed, again no significant difference was found between the low and the high discounts $F(1,51)=2,254, p=0,140$. Thus, in this case, hypothesis 2 is supported.

A question about quality was used as a dependent variable to determine how the participants see the

\section{Table 6 - GLM - Purchase intention}

\begin{tabular}{|l|c|c|c|c|c|}
\hline \multicolumn{8}{|c|}{ Dependent Variable: If you were planning to buy this service, how likely would you be to choose this one? } \\
\hline Source & $\begin{array}{c}\text { Type III Sum of } \\
\text { squares }\end{array}$ & df & Mean square & F & Sig. \\
\hline Corrected model & $21.711^{\text {a }}$ & 4 & 5.428 & 1.645 & 0.171 \\
\hline Intercept & 243.237 & 1 & 243.237 & 73.705 & 0.000 \\
\hline Covariate: frequency & 0.335 & 1 & 0.335 & 0.102 & 0.751 \\
\hline Level of discount & 0.257 & 1 & 0.257 & 0.078 & 0.781 \\
\hline Percentage versus R\$ & 13.102 & 1 & 13.102 & 3.970 & 0.050 \\
\hline Level of discount * percentage versus R\$ & 9.396 & 1 & 9.396 & 2.847 & 0.095 \\
\hline Error & 280.512 & 85 & 3.300 & & \\
\hline Total & 1370.000 & 90 & & & \\
\hline Corrected total & 302.222 & 89 & & & \\
\hline
\end{tabular}

R Squared $=.083$ (Adjusted R Squared $=.059)_{\mathrm{a}}$

\section{Figure 4 - Purchase intention score for each model}

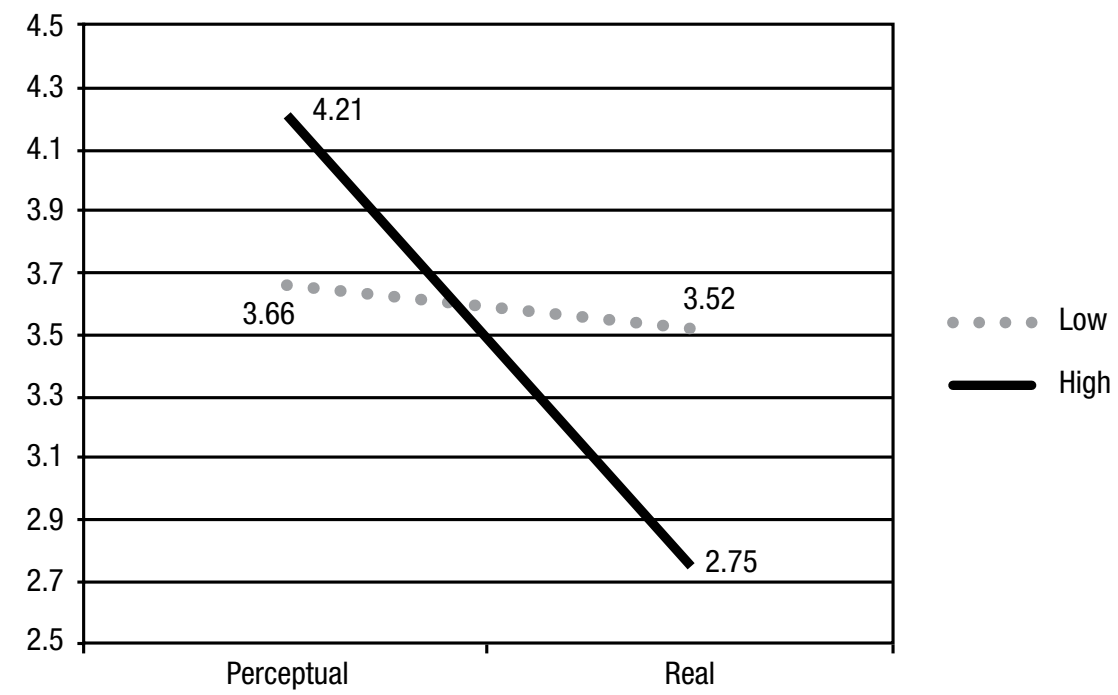


quality of the advertisement. With the use of the GLM, no significant interaction was found between the discount structure and the level of discount $\mathrm{F}(1$, 91) $=0,143 ; \mathrm{p}=0,706$. The means were measured by calculating the covariate in the interaction model as follows: mean $_{\text {Model1 }}=4,230 ;$ mean $_{\text {Model2 }}=3,875 ;$ mean $_{\text {Model3 }}$ $=3,360 ;$ mean $_{\text {Model } 4}=2,744$. The model shows that the discount structure is significant as a main effect $F(1,91)=8,105 ; p=0,006$. The regression is set out in Table 7 and shows that the perception of quality is higher than in the case of Real in terms of percentage, which is in agreement with the H1A. On the basis of the mean averages, it is possible to see if Model 2 is lower than Model 1 and Model 4 is lower than Model
3. These results demonstrate that the quality perception could have an influence on the evaluation process.

\section{CONCLUSIONS: LIMITATIONS AND FUTURE WORK}

The main objective of this paper was to investigate the reaction of consumers to an advertised discount, depending on the type of discounting method employed (absolute value or percentage). Three hypotheses were explored and, the summary of the results is given in Table 8 . The results indicated that the Framing Effect has an impact on the consumer's

\section{Table 7 - GLM - Quality}

Dependent variable: With the sales promotion can I get a better service quality from other services of the same total price?

\begin{tabular}{|l|c|c|c|c|c|}
\hline \multicolumn{1}{|c|}{ Source } & $\begin{array}{c}\text { Type III Sum of } \\
\text { squares }\end{array}$ & df & Mean square & F & Sig. \\
\hline Corrected model & $35.872^{\mathrm{a}}$ & 4 & 8.968 & 3.525 & 0.010 \\
\hline Intercept & 356.942 & 1 & 356.942 & 140.291 & 0.000 \\
\hline Covariate: frequency & 17.260 & 1 & 17.260 & 6.784 & 0.011 \\
\hline Level of discount & 4.940 & 1 & 4.940 & 1.942 & 0.167 \\
\hline Percentage versus R\$ & 20.621 & 1 & 20.621 & 8.105 & 0.006 \\
\hline Level of discount * percentage versus R\$ & 0.364 & 1 & 0.364 & 0.143 & 0.706 \\
\hline Error & 218.810 & 86 & 2.544 & & \\
\hline Total & 1352.000 & 91 & & & \\
\hline Corrected total & 254.681 & 90 & & & \\
\hline R & & & &
\end{tabular}

a. R Squared $=.141$ (Adjusted R Squared $=.101$ )

\section{Table 8 - Summary of the results}

\section{Hypothesis}

H1A: In high discounts, there will be a higher purchasing intention in the offer with percentage discount.

H1B: In low discounts, there will be a higher purchasing intention in the offer in absolute discount.

H2: In a same price situation, the biggest discount will not attract the consumer.

H3: In a situation where a higher discount rate is perceived, there is a decline in quality perception.

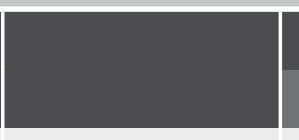

\section{Results}

Experiment 1

Experiment 2

In percentage

In real

In percentage

In real
Supported

Supported

Not supported

Supported

Not completely

Supported
Supported

Not supported

Supported

Supported

Supported 
choice. The differences in the results obtained from the first experiment and $t$ second experiment could be attributed to the different levels of discount offered.

In seeking to explain why H1B was not supported in Experiment 2, one should take into consideration that the low discount used was $\mathrm{R} \$ 25.00$ or $25 \%$, which was probably not deemed to be a big discount by the participants. The same applies to $\mathrm{H} 2$ that was not supported in the first experiment; the difference between $\mathrm{R} \$ 30.00$ and $\mathrm{R} \$ 50.00$ reference prices probably influenced the consumer perception. However, when the reference price was the same ( $\mathrm{R} \$ 100)$, the results were in line with those in previous publications.

The results from the two experiments suggest that quality perception could be a possible moderator of purchase intention, since it is closely linked to the pricing structure. It should be taken into account that other moderators must have an effect on the attraction to the big discount advertisements, for instance, expectation and past experience.

The main outcomes of the experiments support the theory that when the discount value is close to the reference value, it can increase the purchase intent for absolute values (KAHNEMAN and TVERSKY, 1979; THALER, 1985).

Mention should be made of some limitations to this study: this paper only evaluated the purchase intention, and not the real attitude towards purchasing, with a particular group of participants in a laboratory setting. Only two kinds of services were tested. The design tested in the ad was that of Peixe Urbano; perhaps, other web design models might yield better results and make the price discount brighter and clearer.

The present research is relevant to the needs of the Internet media, especially in a collective buying context. We believe that it is also important for the retail industry, as it uses online media for brand exposure, sales promotions and advertisements. Merchandizing is also related to this area. In the case of the academic world, this paper makes a useful contribution by exploring discount services, especially in the Internet. In addition it conducts an analysis of large-scale discounts, a field that has not yet been widely explored. However, as Ailawadi and others (2009) pointed out, there are still many situations that need exploring and theories that need confirmation. The search to find a rational explanation for behavioral changes when a discount is higher than expected is also another avenue to explore and there is a need for practical science in this field. Neuromarketing or neuroeconomics can be used to determine whether the aversion area of the brain is activated when people observe ads with high discounts. Anecdotal evidence passed on by word of mouth can also be studied in this context, since the social media have been increasing each year. As a result, this kind of sales has now become common on a friend-to-friend basis.

\section{NOTE OF APPRECIATION}

The authors are extremely grateful to the RAE editor and their associate editors for their comments, and specially Nam Mi Choi for her English contributions.

\section{REFERENCES}

AILAWADI, K; BEAUCHAMP, J. P; DONTHU, N; GAURI, D. $\mathrm{K}$; SHANKAR, V. Communication and promotion decisions in retailing: a review and directions for future research. Journal of Retailing, v. 85, n. 1, p. 42-55, 2009.

BERENS, G; VAN RIEL, C. B. M; VAN BRUGGEN, G. H. Corporate associations and consumer product responses: the moderating role of corporate brand dominance. Journal of Marketing, v. 69, n. 3, p. 35-48, 2005.

DEGERATU, A; RANGASWAMY, A; WU, J. Consumer choice behavior in online and traditional supermarkets: the effects of brand name, price, and other search attributes. International Journal of Research in Marketing, v. 17, n.1, p. 55-78, 2000.

DELVECCHIO; KRISHANAN, S. H; SMITH, D. C. Cents or percent? The effects of promotion framing on price expectations and choice. Journal of Marketing, v. 71, n. 3, p.158-170, 2007.

DODSON, J. A; TYBOUT, A. M; STERNTHAL, B. Impact of deals and deal retraction on brand switching. Journal of Marketing Research, v. 15, n. 1, p.72-81, 1978.

FIELD, A. Descobrindo a Estatística usando o SPSS. Porto Alegre: Artmed. 2009. 687 p.

FIGUEIREDO, B. R; ÁVILA, G. M. Contabilidade mental 
e mudanças em preços: um estudo experimental. In: ENCONTRO DE MARKETING DA ANPAD, 1, 2004, Porto Alegre. Porto Alegre: ANPAD, 2004.

HEATH, T. B; CHATTERJEE, S; FRANCE, K. R. Mental accounting and change in price: the frame dependence of reference dependence. Journal of Consumer Research, v. 22, p. 90-97, 1995.

KAHNEMAN, D; TVERSKY, A. Prospect theory: an analysis of decision under risk. Econometrica, v. 47, n. 2, p. 263290, 1979.

KAHNEMAN, D; TVERSKY, A. Choices, values, and frames. American Psychologist, v. 39, n. 4, p. 341-350, 1984.

KANNAN, P. K; KOPALlE, P. Dynamic pricing on the internet: importance and implications for consumer behavior. International Journal of Electronic Commerce, v. 5, n. 3, p.63-68, 2011

LICHSTENSTEIN, D. R; RIDGWAY, N. M; NETEMEYER, R. G. Price perceptions and consumer shopping behaviour: a field study. Journal of Marketing Research, v. 30, n. 2, p. 234-245, 1993.

MAGAlHÃES, G. F.. Alimentação é o principal gasto de jovens paulistanos. 2011 Available at: http://www.infomoney.com.br. Access on April 10.2011.

McCONNELL, J. D. Effects of pricing on perception of product quality. Journal of Applied Psychology, v. 52 n. 4, p. 331-334, 1968.

MORWITZ, V. G; GREENLEAF, E. A; JOHNSON, E. J. Divide and prosper: consumers' reactions to partitioned prices. Journal of Marketing Research, v. 35, n. 4, p. 453-463, 1998.

MYERS, R. H; MONTGOMERY, D. C; VINING, G. G. Generalized linear models - with applications in engineering and the sciences. New York: John Wiley \& Sons. 2002. 496 p.

NIEDRICH, R. W; SHARMA, S; WEDELL, D. H. Reference price and price perceptions: a comparison of alternative models. Journal of Consumer Research, v. 28, n. 3, p. 339-354, 2001.

PALAZÓN, M; DELGADO, E. The moderating role of price consciousness on the effectiveness of price discounts and premium promotions. Journal of Product \& Brand Management, v. 18, n. 4, p. 306-312, 2009.
PALAZÓN, M; DELGADO-BALLESTER, E. Effectiveness of price discounts and premium promotions. Psychology $E$ Marketing, v. 26, n. 12, p. 1108-1129, 2009.

PARASURAMAN, A; ZEITHAML, V. A; BERRY, L. L. SERVQUAL: a multiple-item scale for measuring consumer perceptions of service quality. Journal of Retailing, v. 64, n. 1, p. 12-40, 1988.

PESTANA, M. H; GAGEIRO, J. N. Análise de dados para ciências sociais - a complementariedade do SPSS (5a. Edição). Lisboa: Edições Sílabo. 2008. 694 p.

RHA, J.-Y; WIDDOWS, R. The internet and the consumer: countervailing power revisited. Prometheus v. 20, n. 2, p.107-118, 2005.

RUSSO, E; SCHOEMAKER, P. Decision traps. New York: Ed. Doubleday. 1990. 280p.

SERPA, D; AVILA, M. Efeito framing e influência da experiência gerencial em marketing em decisões de compra: um teste experimental. In: XXIV ENCONTRO ANUAL DA ASSOCIAÇÃO DE PROGRAMAS DE PÓS GRADUAÇÃO EM ADMINISTRAÇÃO 2000, Florianópolis. Florianópolis: ANAPAD, 2000.

SERPA, D; AVILA, M. Percepção sobre preço e valor: um teste experimental. RAE-eletrônica, v.3, n.2, Art 13, 2004. Available at: http://www.scielo.br/pdf/raeel/v3n2/v3n2a12. pdf. Access on April 10.2011.

THALER, R. Mental accounting and consumer choice. Marketing Science, v.4, n.3, p.199-214, 1985.

TVERSKY, A; KAHNEMAN, D. The framing of decisions and the psychology of choice. Science, v. 211, p. 453$458,1981$.

VERMA, D. P. S; GUPTA, S. S. Does higher price signal better quality? Vikalpa v. 29, n. 2, p. 67-77, 2004.

VIEIRA, V. A. Verificação da e-TailQ como instrumento para mensurar a qualidade no varejo eletrônico. $R A E-$ Revista de Administração de Empresas, v. 48, n. 4, p.2033, 2008.

ZEITHAML, V. Consumer perceptions of price, quality, and value: a means-end model and synthesis of evidence. Journal of Marketing, v. 52, n. 3, p. 2-22, 1988. 